EDUCATING, EVALUATING, AND SELECTING LIVING KIDNEY DONORS 


\title{
EDUCATING, EVALUATING, AND SELECTING LIVING KIDNEY DONORS
}

\author{
Edited by \\ Robert W. Steiner \\ University of California, \\ UCSD Center for Transplantation, \\ San Diego, U.S.A.
}

\section{KLUWER ACADEMIC PUBLISHERS}

NEW YORK, BOSTON, DORDRECHT, LONDON, MOSCOW 


\section{eBook ISBN: $\quad 1-4020-2276-X$}

Print ISBN: $\quad 1-4020-1271-3$

\section{(C2004 Kluwer Academic Publishers}

\section{New York, Boston, Dordrecht, London, Moscow}

Print @2004 Kluwer Academic Publishers

Dordrecht

\section{All rights reserved}

No part of this eBook may be reproduced or transmitted in any form or by any means, electronic, mechanical, recording, or otherwise, without written consent from the Publisher

\section{Created in the United States of America}

Visit Kluwer Online at: http://kluweronline.com and Kluwer's eBookstore at: http://ebooks.kluweronline.com 


\section{Table of Contents}

Foreword vii

\section{Chapter One}

Ethical Approaches to Living Kidney Donor Education and Acceptance Robert W. Steiner, M.D., William M. Bennett, M.D. and Bernard Gert, Ph.D.

\section{Chapter Two}

Quality of Life and Survival on Dialysis and after Renal Transplantation Paul A. Keown, M.D., DSc., M.B.A.

\section{Chapter Three}

Outcomes for Living Donor and Cadaver Donor Kidney Transplantation Pablo Ruiz-Ramón, M.D. and Lawrence Hunsicker, M.D.

\section{Chapter Four}

The Medical Evaluation and Risk Estimation of End Stage Renal Disease for Living Kidney Donors

Robert W. Steiner, M.D. and Gabriel Danovitch, M.D.

\section{Chapter Five}

The Risk of End Stage Renal Disease for Hypertensive Kidney Donors Scott R. Mullaney, M.D. and Michael G. Ziegler, M.D.

\section{Chapter Six}

Risk of Diabetes and Diabetic Nephropathy

David M. Ward, M.D.

\section{Chapter Seven}

The Education and Counseling Process for Potential Donors and Donor Attitudes after Living Kidney Donation

Robert W. Steiner, M.D. and Christine A. Frederici, L.C.S.W.

\section{Chapter Eight}

Attitudes, Practices, and Ethical Positions among Transplant Centers Concerning Living Kidney Donor Selection

Aaron Spital, M.D.

Index 


\section{Foreword}

This book is intended to provide information and policy and procedure suggestions for centers that perform living donor kidney transplantation. Its purpose is not to argue either for kidney donation for any candidate or against donation for most candidates, but rather to help make the donation process well considered regardless of individual decisions. We look forward to an ongoing effort that will improve and expand the offerings in this volume, to promote defensible kidney donor education, evaluation, and selection.

The Authors 